\title{
Effect of Strain-Induced Precipitation on the Recrystallization Kinetics in a Model Alloy
}

\begin{abstract}
MO JI, MARTIN STRANGWOOD, and CLAIRE DAVIS
The effects of $\mathrm{Nb}$ addition on the recrystallization kinetics and the recrystallized grain size distribution after cold deformation were investigated by using $\mathrm{Fe}-30 \mathrm{Ni}$ and $\mathrm{Fe}-30 \mathrm{Ni}-0.044 \mathrm{wt}$ pct $\mathrm{Nb}$ steel with comparable starting grain size distributions. The samples were deformed to 0.3 strain at room temperature followed by annealing at $950{ }^{\circ} \mathrm{C}$ to $850{ }^{\circ} \mathrm{C}$ for various times; the microstructural evolution and the grain size distribution of non- and fully recrystallized samples were characterized, along with the strain-induced precipitates (SIPs) and their size and volume fraction evolution. It was found that $\mathrm{Nb}$ addition has little effect on recrystallized grain size distribution, whereas $\mathrm{Nb}$ precipitation kinetics (SIP size and number density) affects the recrystallization Avrami exponent depending on the annealing temperature. Faster precipitation coarsening rates at high temperature $\left(950{ }^{\circ} \mathrm{C}\right.$ to $\left.900{ }^{\circ} \mathrm{C}\right)$ led to slower recrystallization kinetics but no change on Avrami exponent, despite precipitation occurring before recrystallization. Whereas a slower precipitation coarsening rate at $850{ }^{\circ} \mathrm{C}$ gave fine-sized strain-induced precipitates that were effective in reducing the recrystallization Avrami exponent after 50 pct of recrystallization. Both solute drag and precipitation pinning effects have been added onto the JMAK model to account the effect of $\mathrm{Nb}$ content on recrystallization Avrami exponent for samples with large grain size distributions.
\end{abstract}

https://doi.org/10.1007/s11661-021-06206-8

(C) The Author(s) 2021

\section{INTRODUCTION}

$\mathrm{NB}$ is often added to steels to retard recrystallization during thermomechanical processing, through effects such as solute drag and precipitate pinning. ${ }^{[1,2]}$ Solute drag effect refers to the retarding force caused by the alloying elements segregating to the migrating boundaries. Precipitate pinning effect is caused by strain-induced precipitates (SIPs) forming during annealing, which pin the migrating boundaries. The spatial distribution of SIPs and their sizes are influenced by the dislocation structures. ${ }^{[3]}$ Though the effect of $\mathrm{Nb}$ on retarding recrystallization in steels after hot deformation has been well studied in the past three decades, the available data of $\mathrm{Nb}$ precipitation kinetics and austenite recrystallization kinetics are rather limited. Model austenitic alloys allow cold deformation data to be garnered to establish a predictive model for recrystallization and precipitation in $\mathrm{Nb}$-containing alloys.

MO JI is with the University of Warwick, Coventry CV4 7AL, UK and also with Brunel University London, Kingston Lane, Uxbridge, London UB8 3PH, UK. Contact e-mail: Mo.Ji@brunel.ac.uk MARTIN STRANGWOOD is with the University of Birmingham, Birmingham B15 2TT, UK and also with the University of Warwick. CLAIRE DAVIS is with the University of Warwick.

Manuscript submitted August 11, 2020; accepted February 13, 2021.

Article published online March 19, 2021
Wang and Zurob measured the precipitation kinetics in a cold-deformed $\mathrm{Ni}-30 \mathrm{Fe}$ alloy with 0.85 wt pet $\mathrm{Nb}$, where the strain level was 0.1 to 0.36 , and the annealing temperature was $700{ }^{\circ} \mathrm{C}$ (heating rate was not specified). It was found that the time for precipitation of 10 pct of the equilibrium precipitate volume fraction occurred at between 20 and 100 seconds, which decreased with increasing strain. ${ }^{[4]}$

The effect of $\mathrm{Nb}(\mathrm{C}, \mathrm{N})$ strain-induced precipitation on the recrystallization kinetics has been reported to retard or even halt the recrystallization process. The Zener pinning equation has been widely applied to describe the recrystallization and precipitation interaction for both cold deformation and annealing and hot deformation processes. $^{[5-8]}$ Different recrystallization Avrami exponents have been observed in both coldand hot-deformed steels, although very few studies have been carried out on SIP and recrystallization interaction after cold deformation. Literature data have been summarized in Table I. It can be seen that the reported recrystallization Avrami exponents vary significantly. More importantly, the effect of SIP on recrystallization mechanism is not consistent: there have been three categories reported in Table I, i.e., recrystallization Avrami exponent did not change compared to $\mathrm{Nb}$-free condition, it decreased, or the recrystallization curve shows a plateau. Zurob et al. pointed out that the shape of a recrystallization curve is determined by both 
Table I. Summary of Effect of SIP on Recrystallization Avrami Exponent

\begin{tabular}{|c|c|c|c|c|c|c|}
\hline \multirow[b]{2}{*}{ References } & \multicolumn{2}{|c|}{ Steel Chemistry } & \multicolumn{3}{|c|}{ Thermomechanical Process } & \multirow[b]{2}{*}{ Recrystallization Avrami Exponent } \\
\hline & Pct $\mathrm{Nb}$ & Pct $\mathrm{C}$ & $\begin{array}{c}\text { Deformation } \\
\text { Temperature }\left({ }^{\circ} \mathrm{C}\right)\end{array}$ & Strain & $\begin{array}{l}\text { Hold or Annealing } \\
\text { Temperature }\left({ }^{\circ} \mathrm{C}\right)\end{array}$ & \\
\hline 20 & $\begin{array}{l}0.16 \\
-\end{array}$ & 0.02 & 1000 & 0.2 & $1075-850$ & $\begin{array}{l}1-2\left(>1025^{\circ} \mathrm{C}\right) \\
\text { Plateau }\left(<1025^{\circ} \mathrm{C}\right) \\
1-2\end{array}$ \\
\hline 21 & $\begin{array}{l}0.03 \\
-\end{array}$ & 0.08 & $1000-850$ & 0.3 & deformation temperature & $\begin{array}{l}1\left(>950{ }^{\circ} \mathrm{C}\right) \\
\text { Plateau }\left(<950{ }^{\circ} \mathrm{C}\right) \\
0.9-1\end{array}$ \\
\hline 22 & $\begin{array}{l}0.03-0.07 \\
-\end{array}$ & 0.1 & 950 & 0.7 & $950-850$ & $\begin{array}{l}0.4-0.7 \\
0.7-0.9\end{array}$ \\
\hline 23 & 0.05 & 0.05 & $1000-900$ & $0.1,0.25$ & deformation temperature & $\begin{array}{l}4\left(>950{ }^{\circ} \mathrm{C}\right) \\
3\left(<950{ }^{\circ} \mathrm{C}\right)\end{array}$ \\
\hline 15 & $\begin{array}{l}0.02 \\
-\end{array}$ & 0.15 & $1000-850$ & $0.25,0.5$ & deformation temperature & $\begin{array}{l}1.5\left(>900^{\circ} \mathrm{C}\right) \\
0.9\left(<900^{\circ} \mathrm{C}\right) \\
1.5\end{array}$ \\
\hline 2 & 0.04 & 0.01 & $1025-900$ & 0.35 & deformation temperature & $\begin{array}{l}0.8\left(>1000^{\circ} \mathrm{C}\right) \\
\text { Plateau }\left(<1000{ }^{\circ} \mathrm{C}\right)\end{array}$ \\
\hline 24 & 0.007 & 0.004 & Cold & 1.6 & $760-600$ & 0.7 \\
\hline 25 & 0.32 & 0.02 & Cold & 1.2 & $750-650$ & 1 \\
\hline
\end{tabular}

recrystallization and precipitation kinetics. ${ }^{[3]}$ Nevertheless, there is still a lack of any predictive approach for describing the effect of SIP on the recrystallization Avrami exponent. Little information was found on the effect of $\mathrm{Nb}$ addition and SIPs on recrystallization grain size distribution evolution, particularly any comparison of recrystallized grain size between $\mathrm{Nb}$-free and $\mathrm{Nb}$-containing steels.

To further understand the effect of $\mathrm{Nb}$ and SIPs on the recrystallization kinetics (Avrami exponent) and grain size distribution, precipitation kinetics and the precipitate size distributions have been determined for $\mathrm{Fe}-30 \mathrm{Ni}$ steels (cold deformed and annealed over a range of conditions). Fe-30Ni steel has been used as a model alloy for recrystallization and precipitation studies after hot deformation. Cizek et al. observed microband substructure in $\mathrm{Fe}-30 \mathrm{Ni}$ steel at $950{ }^{\circ} \mathrm{C}, 0.2$ to 0.8 strain..$^{[9,10]}$ Nagarajan et al. pointed out that the SIPs nucleate and grow on the dislocations and microband structures, and coarsening occurs in seconds after deformation between 0.45 and 1 strain and holding at $850{ }^{\circ} \mathrm{C}$ to $950{ }^{\circ} \mathrm{C}$, for $\mathrm{Fe}-30 \mathrm{Ni}$ steel with a $\mathrm{Nb}$ range of 0.1 to $0.38 \mathrm{wt}$ pet. Typical SIP size is 2 to $15 \mathrm{~nm}$ after holding at $850{ }^{\circ} \mathrm{C}$ to $950{ }^{\circ} \mathrm{C}$ for 100 seconds. ${ }^{[11-13]}$ Black mentioned that recrystallization was halted by SIPs in Fe-30Ni-0.1 wt pet $\mathrm{Nb}$ steels below $1000{ }^{\circ} \mathrm{C} .{ }^{[14]}$ Abdollah-Zadeh claimed that the recrystallization kinetics was retarded by SIPS at $850^{\circ} \mathrm{C}, 0.25$ strain in of Fe-30Ni-0.02 wt pct Nb steel. ${ }^{[15]}$ Poddar et al. observed that SIPs below $10 \mathrm{~nm}$ in diameter could pin the microband structure effectively after hot deformation up to strain of 1 at $925{ }^{\circ} \mathrm{C}$ for $\mathrm{Fe}-30 \mathrm{Ni}-0.1$ wt pet $\mathrm{Nb}$ steel. ${ }^{[16]}$ However, no quantitative effect of precipitation kinetics in $\mathrm{Fe}-\mathrm{Ni}-\mathrm{Nb}$ steels on the recrystallization kinetics and grain size distribution has been reported. Additionally, it has been shown that the dislocation structures produced after cold deformation are comparable with those seen after hot deformation in this material, although it is worth noting that the stored energy from room temperature deformation will not be the same as for the same strain at high temperature. ${ }^{[17,18]}$ Additionally, differences in recovery can arise between cold-deformed and annealed (recovery occurring on heating to the annealing temperature) and hot-deformed (dynamic recovery prior to recrystallization) samples; however, it has been reported that recovery does not affect the recrystallization Avrami exponent, which is being considered in this paper, although it will affect the recrystallization start and finish times. ${ }^{[19]}$

\section{EXPERIMENTAL PROCEDURE}

The materials used in this work are laboratory cast $\mathrm{Fe}-30 \mathrm{Ni}$ ingots with and without a $\mathrm{Nb}$ addition (Table II). Other alloying elements, such as Al and N, were below the detectable levels. Thermo-Calc (TCFE9 database) has been used to calculate the dissolution temperature for precipitates under equilibrium conditions in the $\mathrm{Fe}-30 \mathrm{Ni}-0.044 \mathrm{wt}$ pct $\mathrm{Nb}$ model alloy. The dissolution temperature for $\mathrm{NbC}$ in this $\mathrm{Fe}-30 \mathrm{Ni}-0.044$ wt pet $\mathrm{Nb}$ model alloy is $1010{ }^{\circ} \mathrm{C}$. The $\mathrm{Nb}$-containing steel was homogenized at $1150^{\circ} \mathrm{C}$ for 4 hours to remove any segregation from solidification. The $\mathrm{Nb}$-free steel was reheated to $1300{ }^{\circ} \mathrm{C}$ for 5 minutes to provide comparable starting grain size distributions for the deformation trials. Cylindrical specimens of $10 \mathrm{~mm}$ in diameter and $15 \mathrm{~mm}$ in height were machined from the heat-treated slabs. The specimens were deformed to 0.3 strain at room temperature by uniaxial compression, using an Instron 3300 series static testing machine, lubricated by PTFE film with a strain rate of $2 / \mathrm{min}$, 
before being reheated, at a heating rate of $30{ }^{\circ} \mathrm{C} / \mathrm{s}$, to $950{ }^{\circ} \mathrm{C}, 900{ }^{\circ} \mathrm{C}$, or $850{ }^{\circ} \mathrm{C}$ for various times to give partial and full recrystallization (Table III), followed by quenching into water. Samples were immediately quenched after heating to the holding temperature $(0$ second hold time) to assess the extent of any microstructural/stored energy changes during heating. No barreling was observed for the cold-deformed samples. The deformed and heat-treated specimens were sectioned, mounted in Bakelite and ground, polished, and etched with Kalling's reagent to reveal the austenite grain structures. The recrystallization fraction was determined by point counting from optical images.

Hardness tests were carried out on a Struers DuraScan Micro-hardness tester using a $0.5 \mathrm{~kg}$ load. EBSD samples were prepared using a VibroMet 2 Vibratory Polisher with Buehler MasterMet 2 Colloidal Silica for 2 hours after general polishing to remove any deformation induced during the polishing procedure. EBSD was performed on a JEOL 7800 FEG-SEM. The EBSD step size was $1 \mu \mathrm{m}$, and the local misorientation (between 0 and $5 \mathrm{deg}$, point to point using a filter size of $3 \times 3$ pixels) was calculated by CHANNEL 5 software.

TEM thin foil examination has been performed to investigate the $\mathrm{NbC}$ precipitation behavior after cold deformation to 0.3 strain and the recrystallization heat treatments. TEM was performed using both JEOL 2000FX and JEOL 2100 transmission electron microscopes operated at $200 \mathrm{kV}$; STEM was carried out using a FEI Talos at $200 \mathrm{kV}$. The sample was firstly cut from the bulk specimen as a 1-mm-thick plate using a silicon carbide blade and cooling lubricant. Then, the thin plate was glued onto a Gatan disc grinder to minimize specimen bending or damage. After that, the plate was ground by silicon carbide paper to a thickness of 150 $\mu \mathrm{m}$. Then, a Gatan disc punch was used to cut the plate into several disc specimens with a diameter of $3 \mathrm{~mm}$. Electropolishing was carried out by Struers Tenupol-5 twin-jet electropolisher. For each sample, more than 250

Table II. Composition of the Steels (in Weight Percent)

\begin{tabular}{lccccc}
\hline & $\mathrm{C}$ & $\mathrm{Mn}$ & $\mathrm{S}$ & $\mathrm{Ni}$ & $\mathrm{Nb}$ \\
\hline Nb-Free & 0.061 & 0.52 & 0.009 & 29.95 & - \\
Nb-Containing & 0.061 & 0.53 & 0.01 & 30.01 & 0.044 \\
\hline
\end{tabular}

precipitates over 3 areas were measured with local foil thickness being determined using convergent beam electron diffraction (CBED) techniques. The average sizes of the strain-induced precipitates were between 3 and $10 \mathrm{~nm}$. Due to the limitation of TEM measurement,

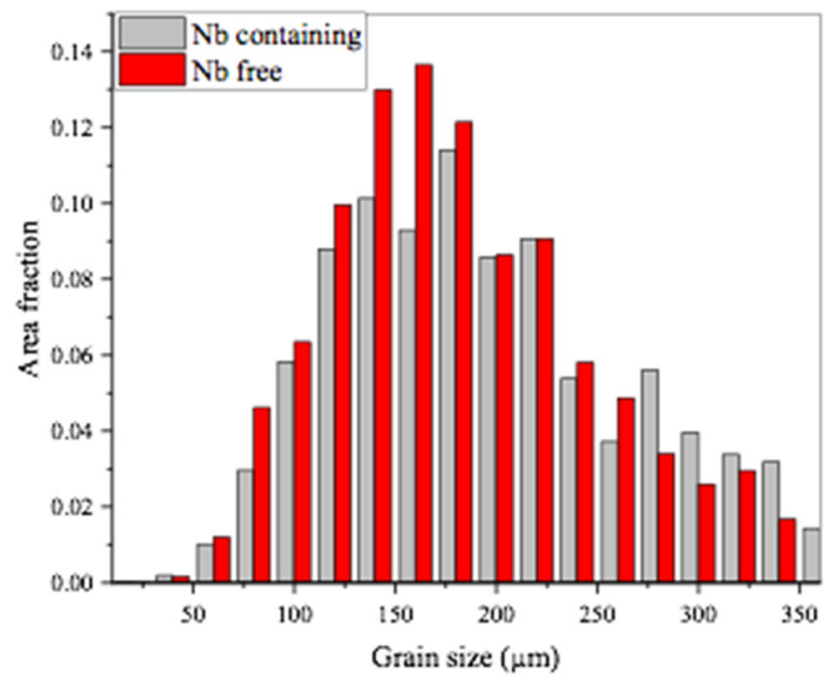

Fig. 1-Grain size distribution for the heat-treated samples (Nb-containing sample was heat treated at $1150{ }^{\circ} \mathrm{C}$ for 4 hours, $\mathrm{Nb}$-free sample was heat treated at $1300{ }^{\circ} \mathrm{C}$ for 5 minutes).

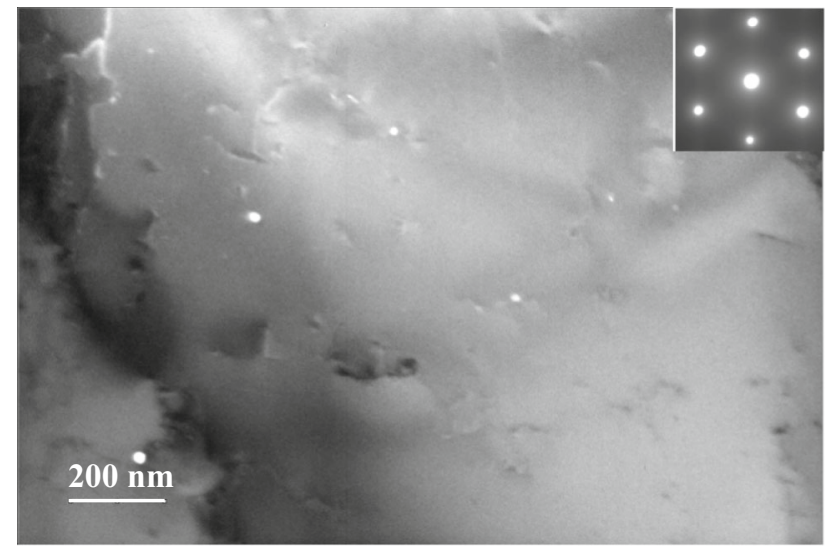

Fig. 2-TEM dark field image of the precipitates (confirmed to be $\mathrm{Nb}$-rich) present after the homogenization treatment $\left(1150^{\circ} \mathrm{C}\right.$ for 4 hours).

Table III. Cold Deformation and Annealing Conditions and Specimens Selected for Recrystallization and SIP Characterization

\begin{tabular}{|c|c|c|c|c|c|}
\hline \multirow{2}{*}{ Steels } & \multicolumn{2}{|c|}{ Conditions } & \multicolumn{2}{|c|}{ Recrystallization Kinetics } & \multirow{2}{*}{$\begin{array}{c}\text { SIP } \\
\text { TEM } t(\mathrm{~s})\end{array}$} \\
\hline & $\varepsilon$ & $T\left({ }^{\circ} \mathrm{C}\right)$ & Optical $t(\mathrm{~s})$ & EBSD $t(\mathrm{~s})$ & \\
\hline \multirow[t]{3}{*}{ Nb-Free } & 0.3 & 950 & $5-60$ & & \\
\hline & & 900 & $10-90$ & & \\
\hline & & 850 & $25-160$ & $25-160$ & \\
\hline \multirow[t]{3}{*}{ Nb-Containing } & 0.3 & 950 & $10-480$ & & $60-120$ \\
\hline & & 900 & $10-300$ & & $120-450$ \\
\hline & & 850 & $60-3600$ & $150-3600$ & $150-3000$ \\
\hline
\end{tabular}


an approximate area of $7 \mu \mathrm{m}^{2}$ was characterized for each condition.

\section{RESULTS}

\section{A. As-homogenized Microstructure}

The initial grain size distributions (equivalent circle diameter, ECD, as the austenite grains are equiaxed) of the heat-treated samples are shown in Figure 1. The $\mathrm{Nb}$-containing specimen has a mode grain size of 160 to $180 \mu \mathrm{m}$ with an area fraction of 0.13 and $95 \mathrm{pct}$ of grains are sized between 80 and $320 \mu \mathrm{m}$. The $\mathrm{Nb}$-free specimen has a mode grain size of 140 to $160 \mu \mathrm{m}$, with an area fraction of 0.12 , and 95 pct of grains are sized between 60 and $320 \mu \mathrm{m}$. Therefore, comparable starting grain size distributions have been utilized to eliminate its effect on the recrystallization Avrami exponent for both $\mathrm{Nb}$-free and $\mathrm{Nb}$-containing $\mathrm{Fe}-30 \mathrm{Ni}$ steel. It has been reported previously that the recrystallization Avrami exponent was 1.4 for the $\mathrm{Nb}$-free material with this grain size distribution, ${ }^{[19]}$ which is in the range reported in Table I.

Figure 2 shows a TEM image of an as-homogenized and undeformed sample. Undissolved precipitates between 10 and $45 \mathrm{~nm}$ in diameter are present, but no fine precipitates $(<5 \mathrm{~nm})$ were observed. The precipitate number density measured by TEM is $4.3 \times 10^{18} \mathrm{~m}^{-3}$. The volume fraction of precipitates was calculated as 1.7 $\times 10^{-5}$, which accounts for 3.5 pct of the total $\mathrm{Nb}$ content in the steel. Therefore, it is not unreasonable to assume the $\mathrm{Nb}$ content in solution is $0.042 \mathrm{wt}$ pct during subsequent recrystallization trials, and that these undissolved precipitates will have an insignificant effect on the recrystallization kinetics. The hardness of the homogenized sample is $110 \pm 2 \mathrm{HV}$ for both $\mathrm{Nb}$-free and $\mathrm{Nb}$-containing steels.

Hardness values for the samples prior to deformation, after cold deformation to 0.3 strain and quenched immediately after reaching the reheating temperature are given in Table IV. Cold deformation to 0.3 strain results in work hardening of the alloys by approximately 90 pct. As expected, reheating results in some softening through recovery processes (by around 17 pct of the cold-deformed hardness). However, the similarity in hardness of the samples when quenched immediately after reaching the different reheating temperatures indicates that the amount of recovery during heating is similar and that recrystallization at the different temperatures would start from comparable dislocation structures and stored energy values.

The dislocation density, $\rho$, and driving force for recrystallization, $F$, were estimated by ${ }^{[26]}$

$$
\sigma=\sigma_{0}+M \alpha G b \sqrt{\rho},
$$

where $M$ is $3.1, \alpha$ is $0.15, G=70 \mathrm{GPa}, b=2.49$ $\times 10^{-10} \mathrm{~m}^{[27]}$ for $\mathrm{Fe}-30 \mathrm{Ni}$ at room temperature. Taking $\sigma_{y} \approx 3 H v$, then

$$
\rho=\left(\frac{3 \times \Delta H v}{M \alpha G b}\right)^{2},
$$

where $\Delta H v$ is the difference in hardness values between after deformation and after reheating.

$$
F=\frac{\rho G^{\prime} b^{2}}{2} \text {. }
$$

$G^{\prime}$ represents the shear modulus at elevated temperature; it is known that the shear modulus decreases with increasing temperature for iron and iron-nickel alloys. ${ }^{[28,29]}$ It has been reported that the shear modulus in an iron-nickel alloy reduces by half at $830{ }^{\circ} \mathrm{C}$ compared to $0{ }^{\circ} \mathrm{C} \cdot{ }^{[28]}$ Additionally, the flow stress curves of $\mathrm{Fe}-30 \mathrm{Ni}$ steels at $950{ }^{\circ} \mathrm{C}$ to $850{ }^{\circ} \mathrm{C}$ indicated that there were little differences in the Young/shear modulus within this temperature range. ${ }^{[15]}$ Therefore, 35 $\mathrm{GPa}$ has been used as the shear modulus for the recrystallization temperatures in this case. The driving force after cold deformation and reheating has been estimated to be $0.54 \mathrm{MPa}$ for 0.3 strain.

\section{B. Recrystallization Measurement}

As for previous studies, ${ }^{[9,10,15,17]}$ the Fe-30Ni steels in this study were obtained from hot rolled, small laboratory casts. However, in this study, the rolled plates were homogenized/heat treated at $1300{ }^{\circ} \mathrm{C}$, which removed compositional and hot rolling strain/structure variations. Thus, while the cold-deformed samples after reheating to and immediate quenching from $950{ }^{\circ} \mathrm{C}$ and $850^{\circ} \mathrm{C}$ showed comparable elongated cell structures (Figures 3(a) and (b)), they do not show the intense microbands noted for hot deformation in the other studies cited. Thus, the results from this study may not precisely relate to hot deformation conditions, but they provide insight through quantification of recrystallization and precipitation effects in the absence of compositional and strain variations. Boundary serrations, noted for higher strain and higher hot deformation temperatures, ${ }^{[15]}$ are often linked to the interaction between microbands and boundaries and so it is not unexpected that they are not readily observed in this study (Figure 3). Figures 3(c) through (f) show the recrystallization evolution of the $\mathrm{Nb}$-free and $\mathrm{Nb}$-containing steels at $850{ }^{\circ} \mathrm{C}$ for a strain of 0.3 . The local misorientation map was applied as an indication of the progress in recrystallization. Recrystallized grains were fine, equiaxed, and deformation-free, i.e., colored in blue. Deformed grains were coarse, elongated, and locally deformed, i.e., areas colored in green. Grain boundaries can be clearly observed in both band contrast and local misorientation map. The recrystallizing grains in both steels nucleated at triple points and along grain boundaries with clustering of recrystallizing grains clearly observed in both cases. No recrystallized grains were observed in the interior of the deformed grains, i.e., shear bands, consistent with previous studies of recrystallization in compressed austenitic steels. ${ }^{[14,15]}$ 
Table IV. Hardness Values for Nb-Containing and Nb-Free Samples in Selected States Prior to the Onset of Recrystallization

\begin{tabular}{lcc}
\hline State & Nb-Free & Nb-Containing \\
\hline Unstrained & $110 \pm 3$ & $210 \pm 3$ \\
Cold Deformed to 0.3 Strain & $175 \pm 5$ & $174 \pm 3$ \\
0.3 Strain Cold Deformation, Reheated to $850^{\circ} \mathrm{C}$ and Immediately Quenched & $175 \pm 3$ & $180 \pm 3$ \\
0.3 Strain Cold Deformation, Reheated to $900^{\circ} \mathrm{C}$ and Immediately Quenched & $175 \pm 2$ \\
0.3 Strain Cold Deformation, Reheated to $950^{\circ} \mathrm{C}$ and Immediately Quenched & 175 \\
\hline
\end{tabular}
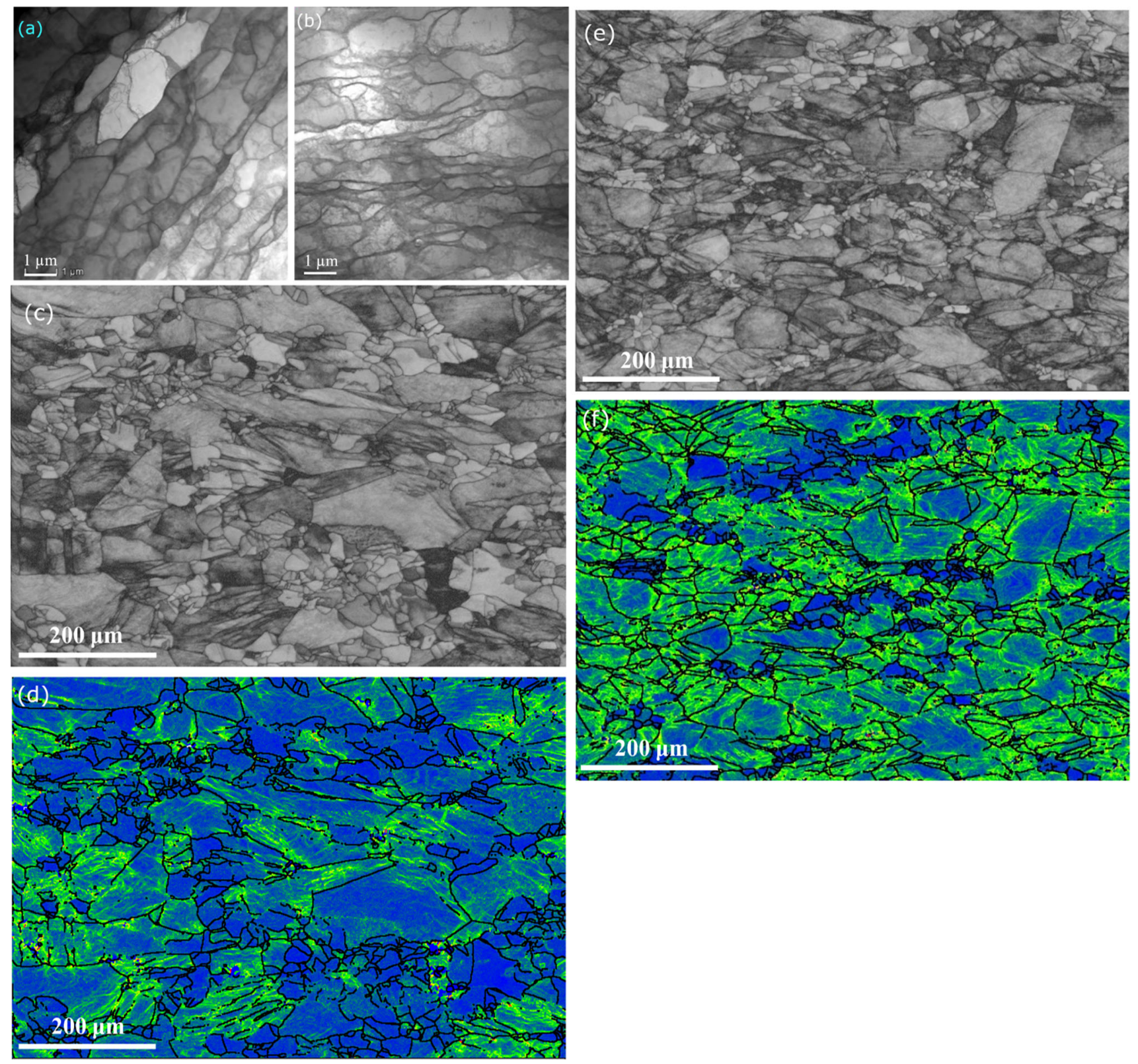

Fig. 3-Microstructure evolution during recrystallization of $\mathrm{Nb}$-free and Nb-containing steels at 0.3 strain $(a)$ recovered cell structure in Fe-30Ni-0.044 wt pct Nb-containing steel immediately quenched after heating to $950{ }^{\circ} \mathrm{C},(b)$ recovered cell structure in $\mathrm{Fe}-30 \mathrm{Ni}-0.044 \mathrm{wt}$ pct $\mathrm{Nb}$ immediately quenched after heating to $850{ }^{\circ} \mathrm{C},(c)$ after 40 seconds at $850{ }^{\circ} \mathrm{C}$, Nb-free steel, band contrast, $(d)$ after 40 seconds at $850{ }^{\circ} \mathrm{C}$, $\mathrm{Nb}$-free steel, local misorientation, (e) after 300 seconds at $850{ }^{\circ} \mathrm{C}$, Nb-containing steel, band contrast, and $(f)$ after 300 seconds at $850{ }^{\circ} \mathrm{C}$, $\mathrm{Nb}$-containing steel, local misorientation. 
Fig. 5-The recrystallized grain size distributions of $\mathrm{Nb}$-free and $\mathrm{Nb}$-containing steels after 0.3 strain and full annealing at $(a) 850{ }^{\circ} \mathrm{C}$ (3600 seconds for $\mathrm{Nb}$-containing steel, 160 seconds for $\mathrm{Nb}$-free steel), (b) $900{ }^{\circ} \mathrm{C}$ (450 seconds for $\mathrm{Nb}$-containing steel, 90 seconds for $\mathrm{Nb}$-free steel), and (c) $950{ }^{\circ} \mathrm{C}$ (160 seconds for $\mathrm{Nb}$-containing steel, 60 seconds for $\mathrm{Nb}$-free steel).

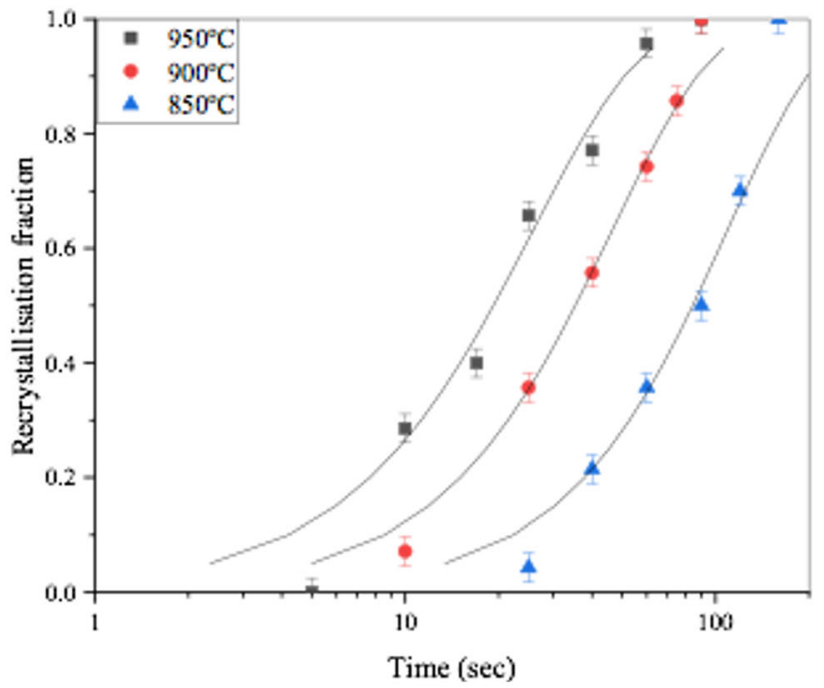

(a)

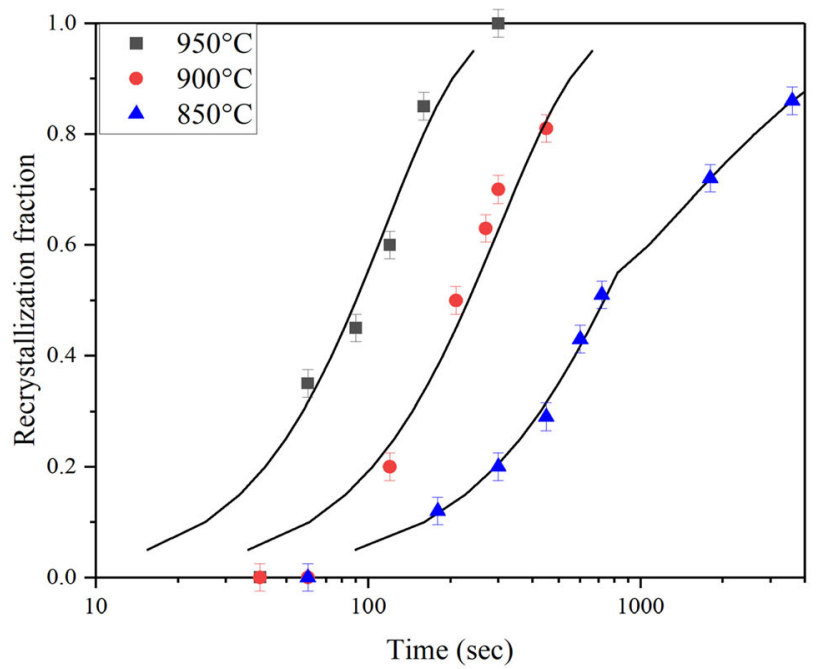

(b)

Fig. 4-Recrystallization kinetics of $\mathrm{Fe}-30 \mathrm{Ni} \mathrm{Nb}-$ free steel $(a)$ and Fe-30Ni-0.044 wt pet $\mathrm{Nb}$ steel $(b)$ at 0.3 strain.

Table V. Summary of Avrami Exponents Under Different Conditions

\begin{tabular}{lccc}
\hline \multirow{2}{*}{ Strain } & Temperature $\left({ }^{\circ} \mathrm{C}\right)$ & \multicolumn{2}{c}{ Avrami Exponent } \\
& & Nb-Free & Nb-Containing \\
\hline 0.3 & 950 & 1.2 & 1.4 \\
& 900 & 1.3 & 1.4 \\
& 850 & 1.4 & $1.3(<720 \mathrm{~s})$ \\
& & & $0.6(>720 \mathrm{~s})$ \\
\hline
\end{tabular}

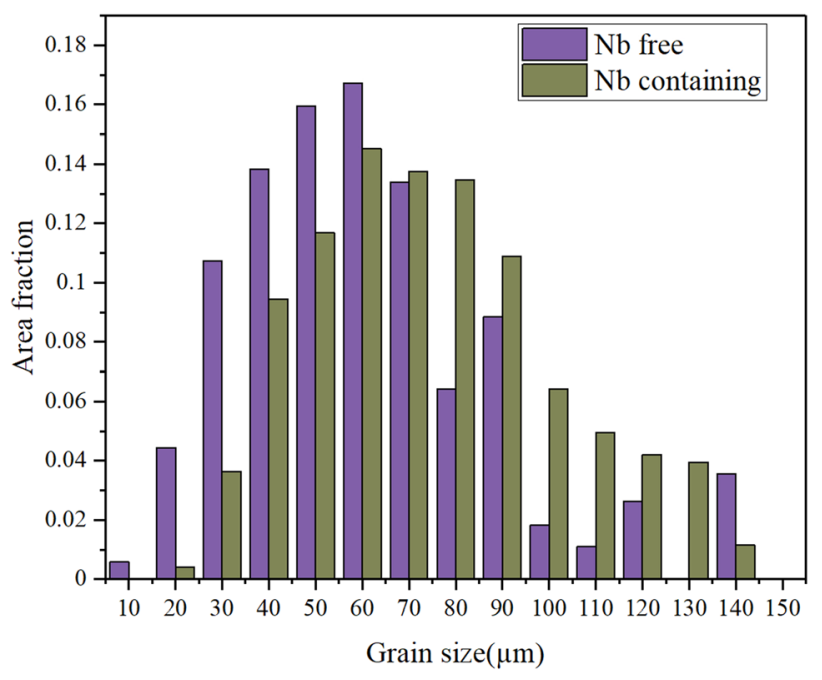

(a)

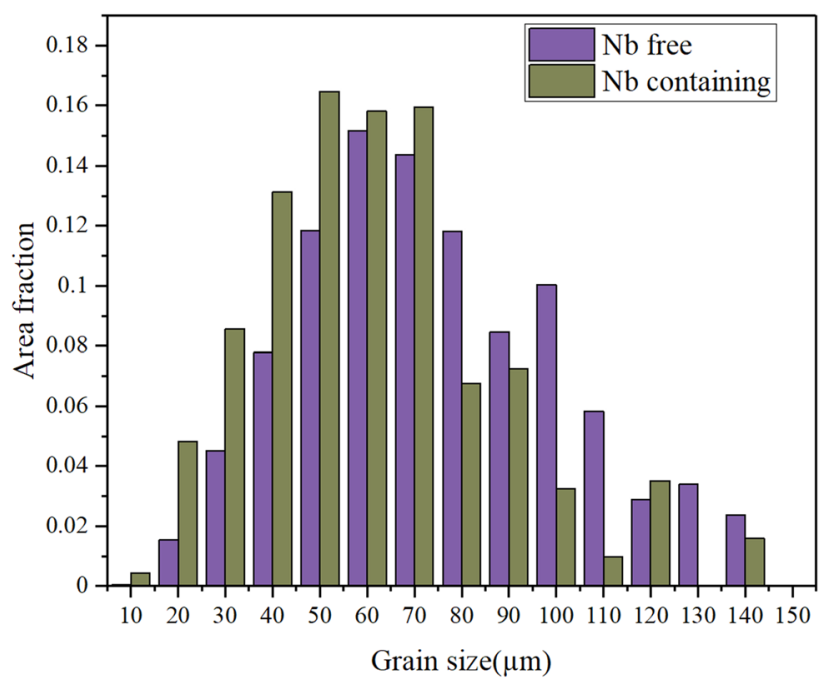

(b)

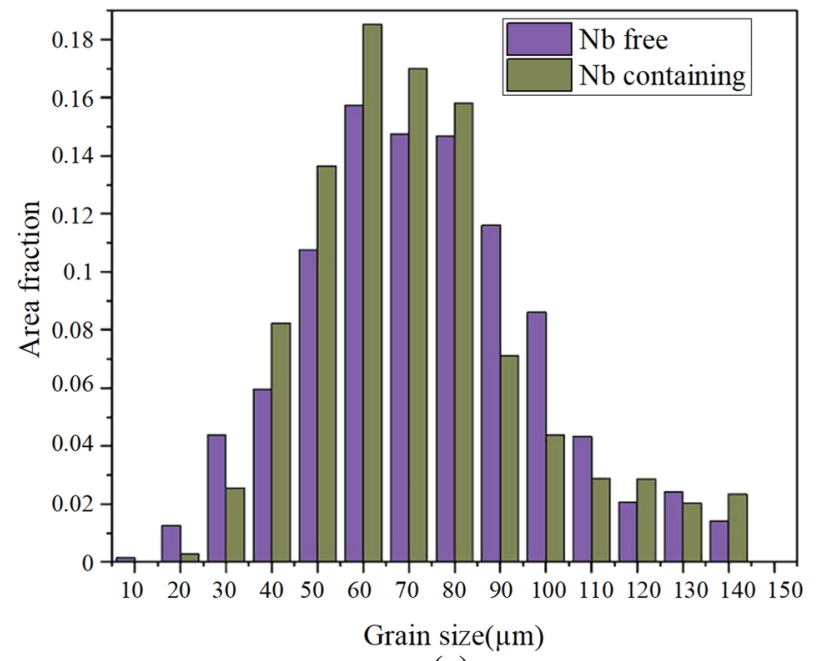

(c) 

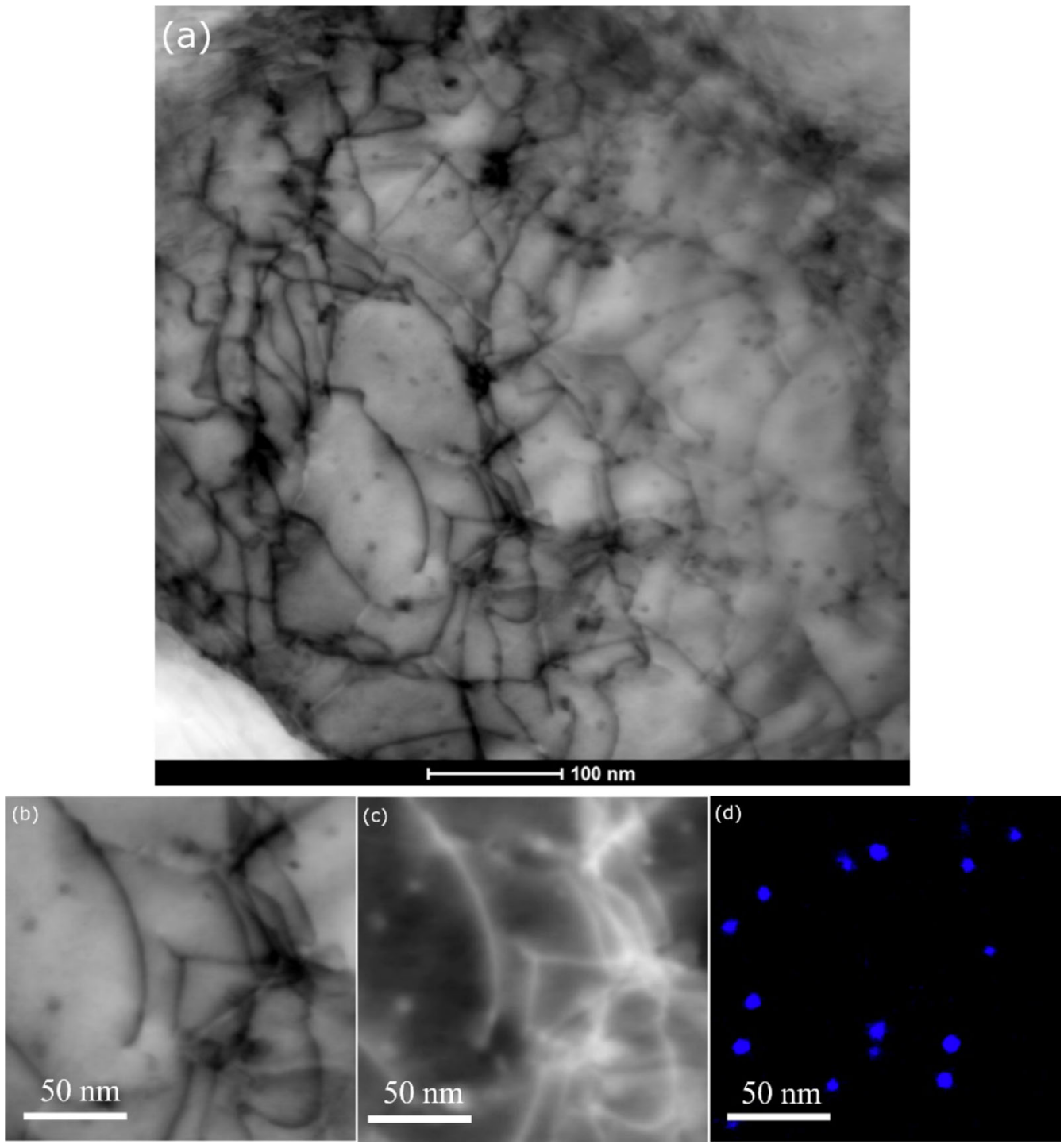

Fig. 6-STEM images showing the interaction between strain-induced precipitates and the dislocation substructures during recrystallization at $850{ }^{\circ} \mathrm{C}, 0.3$ strain, annealed for 120 seconds. (a) Low-magnification bright field, (b) high-magnification bright field, (c) high-magnification HAADF, and $(d)$ EDS mapping showing $\mathrm{Nb}$ distribution.

Figure 4 summarizes the recrystallization kinetics for the $\mathrm{Nb}$-free and $\mathrm{Nb}$-containing steels at $950{ }^{\circ} \mathrm{C}$ to $850^{\circ} \mathrm{C}$ after 0.3 strain. The experimental results show that approximately 85 pct recrystallization was completed within the temperature range of $950{ }^{\circ} \mathrm{C}$ to 850 ${ }^{\circ} \mathrm{C}$ for the annealing times used, showing that precipitation does not halt recrystallization. There is an apparent delay in the recrystallization starting time and in the overall time for completion of recrystallization caused by the $\mathrm{Nb}$ addition (compared to measurements for the $\mathrm{Nb}$-free condition) as expected and widely reported. The results in Figure 4 suggest that the $\mathrm{Nb}$ addition causes an order of magnitude delay in the time of the onset of recrystallization. All recrystallization curves have been fitted to the JMAK equation:

$$
X=1-\exp \left(-k t^{n}\right)
$$

where $X$ is the recrystallization fraction at time $t, k$ is rate parameter determined by the recrystallization nucleation and growth rate, and $n$ is the Avrami exponent. While recrystallization kinetics in the $\mathrm{Nb}$-free steel and for $\mathrm{Nb}$-containing steel at the higher two temperatures are fitted by a single Avrami curve, the recrystallization curve for the $\mathrm{Nb}$-containing steel at 850 ${ }^{\circ} \mathrm{C}$ and 0.3 strain was fitted by two regions, as significant slower recrystallization rate was observed after 720 seconds of annealing, i.e., approximately 0.5 recrystallization fraction.

Table V summarizes the measured Avrami exponents for the $\mathrm{Nb}$-free and $\mathrm{Nb}$-containing alloys and the relatively low Avrami exponents reported here (1.3 to 1.4) are consistent with the model proposed for the effect of the grain size distribution on Avrami exponent. ${ }^{[19]}$ It can be seen that the presence of $\mathrm{Nb}$ has no effect on the Avrami exponents for annealing at $900{ }^{\circ} \mathrm{C}$ and $950{ }^{\circ} \mathrm{C}$, 

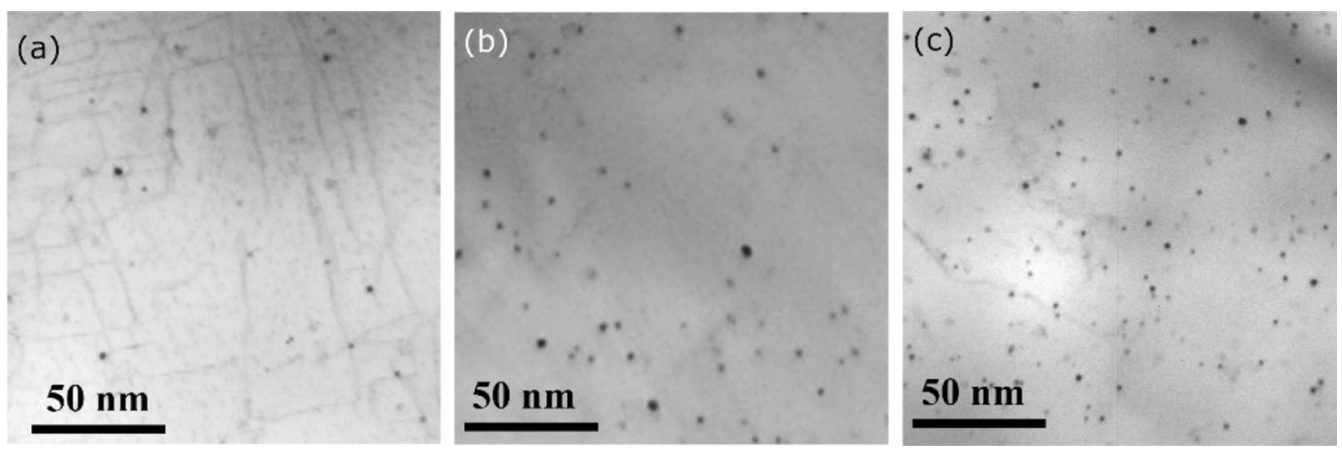

Fig. 7- Strain-induced precipitates (TEM bright field image observed in the Fe-30Ni Nb-containing steel specimens after 0.3 strain and at early stage of recrystallization, where $D$ is the average precipitate diameter. (a) $T=850{ }^{\circ} \mathrm{C}, 120$ seconds, $R_{\mathrm{ex}}=9 \mathrm{pct}, D=4.4 \pm 0.2 \mathrm{~nm},(b) T=$ $900{ }^{\circ} \mathrm{C}, 120$ seconds, $R_{\mathrm{ex}}=20 \mathrm{pct}, D=5.9 \pm 0.2 \mathrm{~nm}$, and $(c) T=950{ }^{\circ} \mathrm{C}, 60$ seconds, $R_{\mathrm{ex}}=35 \mathrm{pct}, D=4.6 \pm 0.4 \mathrm{~nm}$.
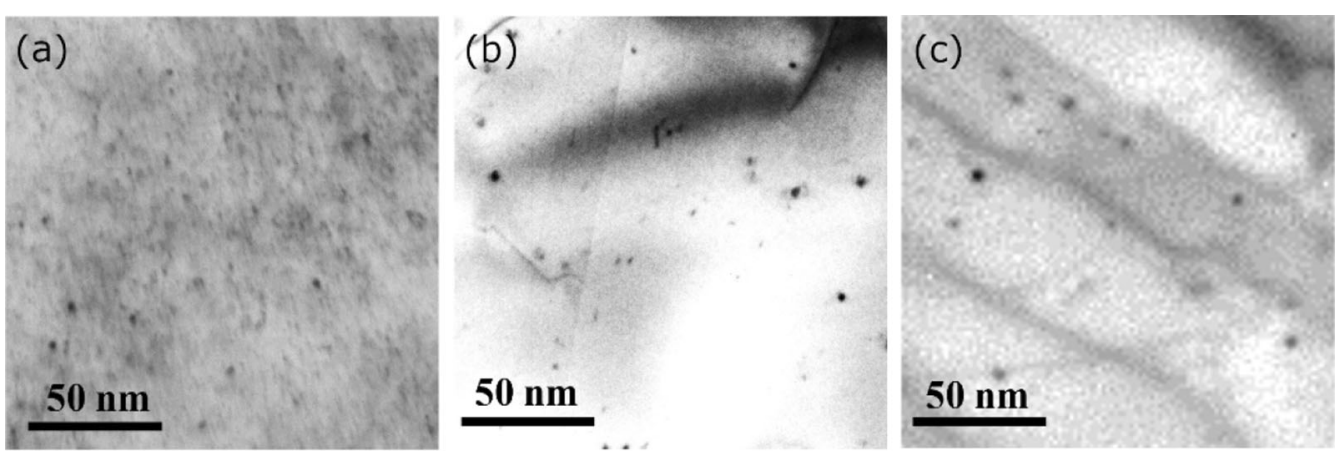

Fig. 8- Strain-induced precipitates (TEM bright field image observed in the Fe-30Ni Nb-containing steel specimens after 0.3 strain and at a later stage of recrystallization, where $D$ is the average precipitate diameter. $(a) T=850{ }^{\circ} \mathrm{C}, 3000$ seconds, $R_{\mathrm{ex}}=82 \mathrm{pct}, D=6.1 \pm 0.3 \mathrm{~nm},(b) T=$ $900{ }^{\circ} \mathrm{C}, 450$ seconds, $R_{\mathrm{ex}}=81 \mathrm{pct}, D=8.5 \pm 0.4 \mathrm{~nm}$, and $(c) T=950{ }^{\circ} \mathrm{C}, 160$ seconds, $R_{\mathrm{ex}}=85$ pct, $D=10.4 \pm 0.2$.

although it affects recrystallization nucleation as evidenced by the delay in the recrystallization start time as well as slowing overall recrystallization kinetics. However, for annealing at $850{ }^{\circ} \mathrm{C}$, there is a decrease in Avrami exponent from 1.3 to 0.6 during recrystallization, fitted line in Figure 4(b). The data appear to show a comparable slope to $950{ }^{\circ} \mathrm{C}$ and $900{ }^{\circ} \mathrm{C}$, for a recrystallized fraction up to $50 \mathrm{pct}$, suggesting that it is the later stages of recrystallization that are affected by the $\mathrm{Nb}$ addition at $850^{\circ} \mathrm{C}$.

Figure 5 summarizes the recrystallized grain size distribution of the $\mathrm{Nb}$-free and $\mathrm{Nb}$-containing steels after annealing at $950{ }^{\circ} \mathrm{C}$ to $850{ }^{\circ} \mathrm{C}$. The fully recrystallized grain size distributions are comparable for all three annealing temperatures, consistent with comparable stored energy after being reheated to the annealing temperatures $\left(950{ }^{\circ} \mathrm{C}\right.$ to $\left.850{ }^{\circ} \mathrm{C}\right)$. The $\mathrm{Nb}$-containing steels have a mode grain size of 50 to $60 \mu \mathrm{m}$ with an area fraction of 0.15 to 0.18 and $95 \mathrm{pct}$ of grains are sized between 30 and $120 \mu \mathrm{m}$. The $\mathrm{Nb}$-free steel has a mode grain size of 50 to $60 \mu \mathrm{m}$ with an area fraction of 0.14 to 0.16 and 95 pct of grains are sized between 30 and $120 \mu \mathrm{m}$. The comparable recrystallized grain size distribution between $\mathrm{Nb}$-free and $\mathrm{Nb}$-containing steels indicated that the $\mathrm{Nb}$ addition has no significant effect on changing the total number of the recrystallization nuclei and hence final grain size distribution.

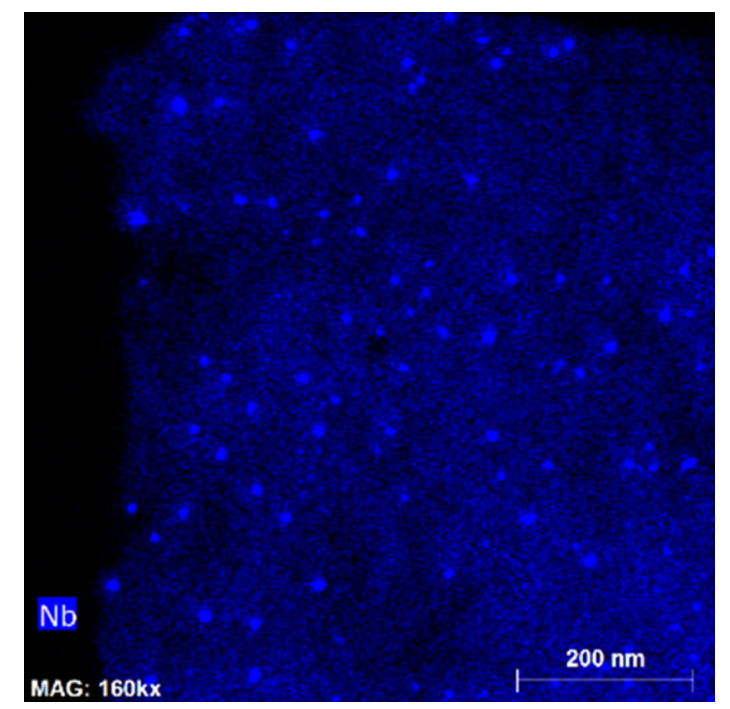

Fig. 9-EDX mapping of the specimens deformed at 0.3 strain and annealed at $850{ }^{\circ} \mathrm{C}, 120$ seconds showing the precipitates to be Nb-rich.

\section{NbC Precipitate Characterization}

Strain-induced precipitates (SIPs) were observed in all the samples after 0.3 strain and holding at $950{ }^{\circ} \mathrm{C}$ to 850 ${ }^{\circ} \mathrm{C}$. It is known that strain-induced precipitates nucleate 


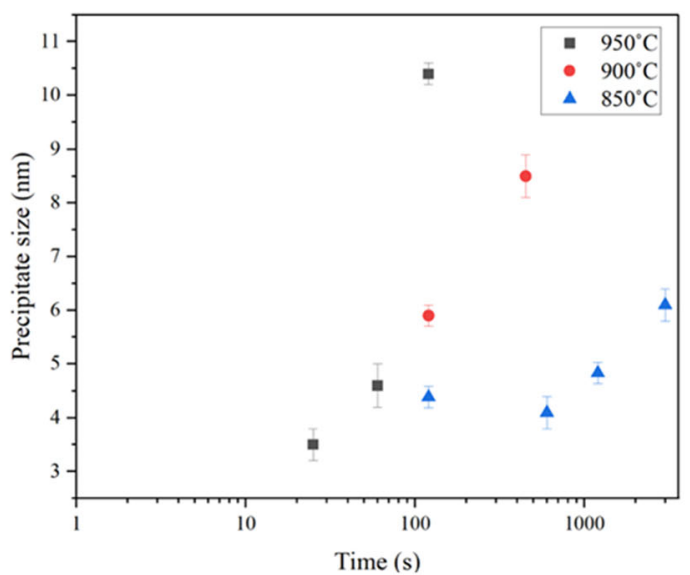

(a)

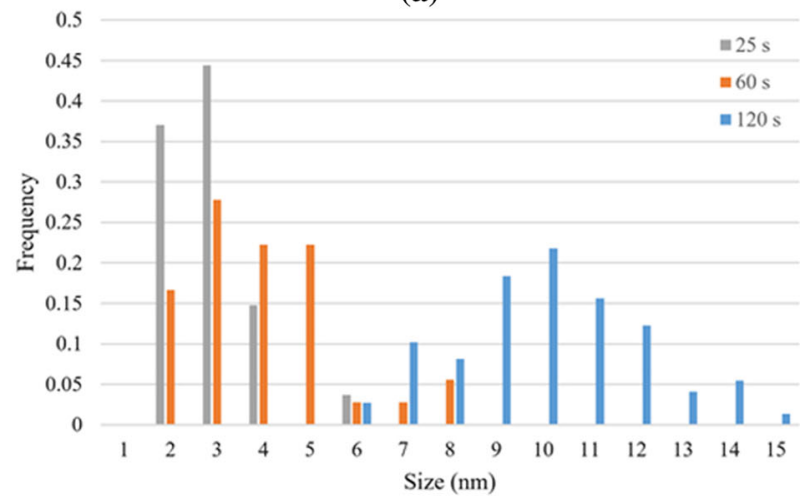

(b)

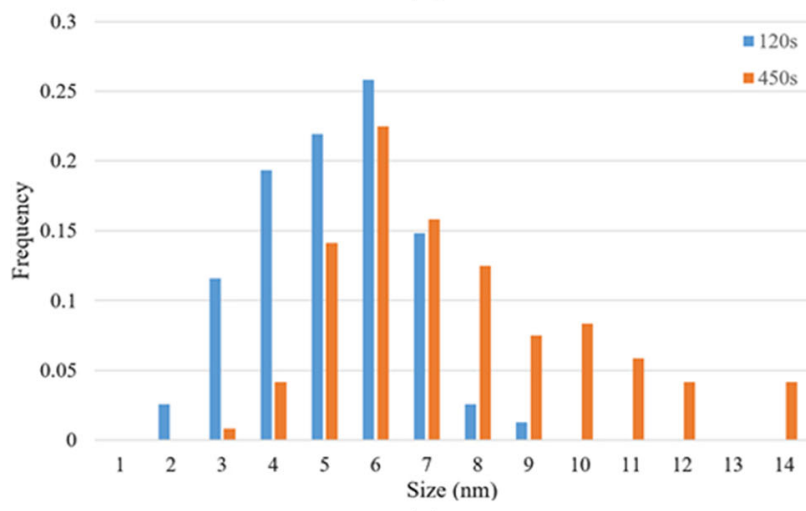

(c)

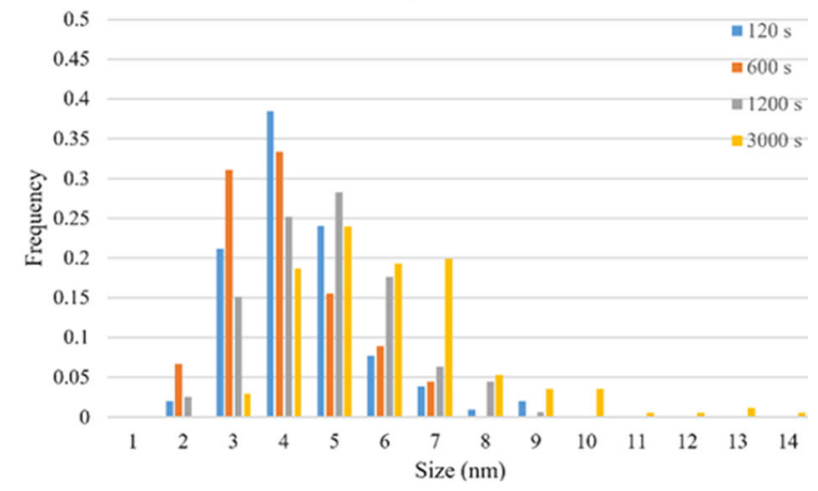

(d)
4Fig. 10-Strain-induced precipitate size evolution at various recrystallization temperatures after cold deformation to 0.3 strain. (a) Average SIP size, (b) SIP size distribution at $950{ }^{\circ} \mathrm{C}$, (c) SIP size distribution at $900{ }^{\circ} \mathrm{C}$, and $(d)$ SIP size distribution at $850{ }^{\circ} \mathrm{C}$.

and grow on dislocation networks ${ }^{[17]}$; Figure 6 confirms the links between SIP and dislocations in the Nb-containing steel. Analysis of the overall recrystallization kinetics, Figure 4 and Table V, shows that the addition of $\mathrm{Nb}$ slows the overall kinetics, but without change in the Avrami $n$ parameter apart from recrystallization beyond a fraction of 0.5 at $850{ }^{\circ} \mathrm{C}$; characterization of the SIPs was carried out to identify reasons for this behavior.

Figure 7 shows SIPs at an early stage of recrystallization. It can be seen that SIPs were located on the subgrain network. The interspacing between SIPs is around $100 \mathrm{~nm}$, i.e., one magnitude smaller than the subgrain diameter prior to recrystallization. It suggests that the strain-induced precipitates, in this case, had formed when the subgrains/dislocation cells were still very small, i.e., at the very early stage of recovery, prior to recrystallization. Figure 8 shows SIPs at a later stage of recrystallization. The subgrain network and precipitation arrangement have disappeared after 450 seconds at $900{ }^{\circ} \mathrm{C}$ (81 pct recrystallization), whereas these were still observable after 300 seconds at $850{ }^{\circ} \mathrm{C}(55 \mathrm{pct}$ recrystallization). This would indicate that SIPs are not coarsening significantly for a prolonged period at $850{ }^{\circ} \mathrm{C}$ and so could continue to slow recrystallization. EDS mapping has been carried out on these samples to confirm that the observed precipitates are $\mathrm{Nb}$-based (Figure 9).

Figure 10 shows the different trends for the three annealing temperatures. For the times investigated, the precipitates observed for annealing at 900 and $950{ }^{\circ} \mathrm{C}$ show an increasing size and reducing number density, which indicates that the increased volume fraction is driven by growth processes rather than increased nucleation. The time exponents for this growth stage are in the range 0.2 to 0.25 , values that are commonly seen for coarsening of precipitate arrays in other systems. ${ }^{[8,22]}$ It is expected that the growth is controlled by pipe (early stages) or bulk (late stages) diffusion of $\mathrm{Nb}$. The situation differs for annealing at a temperature of $850{ }^{\circ} \mathrm{C}$, where the number density continues to increase for times up to and including 1200 seconds; TEM results, Figure 7, indicate that these precipitates are still arranged in a subgrain boundary network. The mean size of the SIPs remains in the range 4 to $5 \mathrm{~nm}$ for annealing times up to 1200 seconds, which indicates that nucleation dominates at this temperature rather than growth (pipe diffusion of $\mathrm{Nb}$-controlled). Additionally, the SIP size distributions at various temperatures are shown in Figure 10. These size distributions are generally smooth, which can be taken as an indication that sufficient particles have been measured in these conditions. The distributions also clearly indicate growth of the precipitate sizes for the times investigated at $950{ }^{\circ} \mathrm{C}$ 
and $900{ }^{\circ} \mathrm{C}$; growth at $850{ }^{\circ} \mathrm{C}$ is less with more overlap between the distributions for the four times studied.

The mean sizes of the SIPs observed for annealing in the temperature range $950{ }^{\circ} \mathrm{C}$ to $850{ }^{\circ} \mathrm{C}$ after 0.3 strain are summarized in Table VI. The mean precipitate size formed at higher temperature is much larger than at lower temperatures for the same holding time. It can be seen that the precipitate size increases significantly during the holding time from 60 to 120 seconds for the recrystallization temperature of $950{ }^{\circ} \mathrm{C}$. The mean SIP size increased from $3.5 \mathrm{~nm}$ after 60 seconds to $10.4 \mathrm{~nm}$ at 120 seconds. However, the average precipitate size was $5.2 \mathrm{~nm}$ at $900{ }^{\circ} \mathrm{C}$ and $4.3 \mathrm{~nm}$ at $850{ }^{\circ} \mathrm{C}$ for 120 seconds, showing little coarsening with time, with growth being slow at $850^{\circ} \mathrm{C}$, that is, the mean SIP size only increased from 4 to $6 \mathrm{~nm}$ after holding at $850{ }^{\circ} \mathrm{C}$ for 3000 seconds. Number densities are given in Table VI based on CBED-derived foil thicknesses. The thicknesses determined were far greater than the precipitate size. As noted above, sufficient precipitates have been measured to give reasonable size distributions and so the experimental error in determining number density will be in thickness determination; this would not be sufficient to reverse the trends in number density shown in Table VI. The latter indicate that coarsening is occurring prior to full precipitation. The early onset of SIP coarsening before reaching equilibrium has been reported by Dutta et $a l^{[8,30]}$ and would be consistent with coarsening via pipe diffusion of precipitate clusters formed on dislocation networks at a faster rate than supply of $\mathrm{Nb}$ by volume diffusion to give precipitate growth.

The volume fraction of SIPs has been compared with the equilibrium volume fraction of $\mathrm{NbC}$ (from ThermoCalc) at each temperature. From these values, the amount of $\mathrm{Nb}$ remaining in solid solution for the various times at each temperature has also been determined. These data indicate that in most of the cases represented there is a combination of $\mathrm{Nb}$ in solution and $\mathrm{NbC}$ SIP distributions. Therefore, both solute drag and Zener pinning can act to modify the recrystallization Avrami exponent.

\section{DISCUSSION}

To account for both the effect of precipitate pinning and solute drag on recrystallization kinetics, the pinning force and reduced boundary mobility have been calculated using the data from Table VI. The pinning force is given by Zurob,

$$
F_{\mathrm{p}}=\frac{3 \gamma f}{2 r},
$$

where $\gamma$ is the interfacial energy, $f$ is the volume fraction of SIP, and $r$ is the radius of the SIP.

Zurob mentioned that the boundary mobility is affected by the $\mathrm{Nb}$ content level in solution, ${ }^{[30]}$ which is given as

$$
M(t)=\left(\frac{1}{M_{\text {pure }}}+\alpha C_{\mathrm{Nb}}\right)^{-1,}
$$

where

$$
\begin{gathered}
\alpha=\frac{\beta(k T)^{2}}{E_{\mathrm{b}} D}\left(\sinh \left(\frac{E_{\mathrm{b}}}{k T}\right)-\frac{E_{\mathrm{b}}}{k T}\right), \\
M_{\text {pure }}=\frac{0.192}{T} \exp \left(\frac{-20837.14}{T}\right) .
\end{gathered}
$$

In Eq. [7], $\beta$ is the grain boundary width (taken to be 1 $\mathrm{nm}), k$ is the Boltzmann constant, $E_{\mathrm{b}}$ is the solute boundary binding energy $(25 \mathrm{~kJ} / \mathrm{mol}), D$ is the bulk diffusivity of $\mathrm{Nb}$ in austenite $\left(1.4 \times 10^{-4} \exp (-270,000 /\right.$ $R T) \mathrm{m}^{2} / \mathrm{s}$, and $T$ is the temperature. These values are summarized by Dutta and Zurob. ${ }^{[31]}$

The estimated local pinning force and mobility are shown in Table VII for the samples after 0.3 strain. It can be seen that the local pinning force at $950{ }^{\circ} \mathrm{C}$ is 0.18 $\mathrm{MPa}$ compared to $0.12 \mathrm{MPa}$ at $850{ }^{\circ} \mathrm{C}$ at the onset of recrystallization, and the pinning force increases gradually at $950{ }^{\circ} \mathrm{C}, 120$ seconds to $0.28 \mathrm{MPa}$. The pinning force at $950{ }^{\circ} \mathrm{C}$ was insufficient to stop recrystallization completely but was high enough to retard the onset of recrystallization and slow the rate. At $900{ }^{\circ} \mathrm{C}$, the strain-induced precipitates are also expected to be already present at the onset of recrystallization, e.g., they were observed after 120 seconds at 20 pct of recrystallization where the SIPs are already $5.9 \mathrm{~nm}$ in size, leading to a sluggish onset of recrystallization. The pinning force increases from 0.17 to $0.27 \mathrm{MPa}$ during annealing at $900{ }^{\circ} \mathrm{C}$. However, at $850{ }^{\circ} \mathrm{C}$, the pinning force increased significantly with time, attributed to the slow precipitation growth rate at $850{ }^{\circ} \mathrm{C}$ up to 3000 seconds and increasing number density of SIPs (to 1200 seconds) indicating additional precipitation is occurring. The boundary mobility is affected by the $\mathrm{Nb}$ content, which increases with decreasing $\mathrm{Nb}$ solute atoms in the matrix as precipitation proceeds.

However, the mobility values calculated for annealing at $850{ }^{\circ} \mathrm{C}$ are still considerably lower than those at 900 ${ }^{\circ} \mathrm{C}$ and $950{ }^{\circ} \mathrm{C}$ indicating that a markedly greater slowing of the recrystallization process will occur from solute drag at the lowest temperature. The boundary mobility increases as a result of $\mathrm{Nb}$ depletion during precipitation, and the trade-off between solute drag and precipitation pinning leads to a change in the recrystallization kinetics and Avrami exponent. The Avrami exponents in both $\mathrm{Nb}$-free and $\mathrm{Nb}$-containing steels are below those expected theoretically. Previous work has identified strain inhomogeneity ${ }^{[32,33]}$ and grain size distributions ${ }^{[19]}$ as contributing factors to reductions in Avrami exponent. These both need to be considered for their potential effects on the Avrami exponent in the $\mathrm{Nb}$-free steel. In this study, as noted above, there is no barreling and so macroscopic strain distribution can be considered uniform. The initial grain size distributions in the two steels in this study are also relatively coarse (see above) with 95 pct of the grains being above 60 to $80 \mu \mathrm{m}$. Although there is uniform macrostrain, microscopic strain variations could still be present due to grain size and texture differences. Both steels have been 
Table VI. Size, Number Density, Volume Fraction of NbC Strain-Induced Precipitates After 0.3 Strain and Annealing at Temperatures in the Range $950{ }^{\circ} \mathrm{C}$ to $850{ }^{\circ} \mathrm{C}$ for Various Times

\begin{tabular}{|c|c|c|c|c|c|}
\hline Temperature $\left({ }^{\circ} \mathrm{C}\right)$ & Time (s) & Mean Size (nm) & Number Density $\left(\times 10^{21} / \mathrm{m}^{3}\right)$ & Volume Fraction & Equilibrium Percentage \\
\hline \multirow[t]{3}{*}{950} & 25 & 3.5 & $3.15 \pm 0.37$ & 0.000071 & 26 \\
\hline & 60 & 4.6 & $2.24 \pm 0.46$ & 0.000114 & 42 \\
\hline & 120 & 10.4 & $0.55 \pm 0.11$ & 0.00027 & 100 \\
\hline \multirow[t]{2}{*}{900} & 120 & 5.9 & $1.05 \pm 0.08$ & 0.00011 & 26 \\
\hline & 450 & 8.5 & $0.8 \pm 0.13$ & 0.00026 & 62 \\
\hline \multirow[t]{4}{*}{850} & 120 & 4.4 & $1.34 \pm 0.2$ & 0.000059 & 12 \\
\hline & 600 & 4.1 & $2.28 \pm 0.15$ & 0.000078 & 16 \\
\hline & 1200 & 4.8 & $3.63 \pm 0.32$ & 0.00021 & 44 \\
\hline & 3000 & 6.1 & $2.85 \pm 0.33$ & 0.00033 & 69 \\
\hline
\end{tabular}

The $\mathrm{Nb}$ content remaining in solution is also listed.

Table VII. Number Density of NbC Strain-Induced Precipitates and Boundary Mobility After 0.3 Strain and Recrystallization at Temperatures of $950{ }^{\circ} \mathrm{C}$ to $850{ }^{\circ} \mathrm{C}$ for Various Times

\begin{tabular}{lcccccc}
\hline $\begin{array}{l}\text { Temperature } \\
\left({ }^{\circ} \mathrm{C}\right)\end{array}$ & $\begin{array}{c}\text { Time } \\
(\mathrm{s})\end{array}$ & $\begin{array}{c}\text { Recrystallized } \\
\text { Fraction }\end{array}$ & $\begin{array}{c}\text { SIP Size } \\
(\mathrm{nm})\end{array}$ & $\begin{array}{c}\text { Number Density }(\times \\
\left.10^{21} / \mathrm{m}^{3}\right)\end{array}$ & $\begin{array}{c}\text { Zener Pinning Force } \\
(\mathrm{MPa})\end{array}$ & $\begin{array}{c}\text { Boundary Mobility } \\
(\mathrm{m} /\end{array}$ \\
\hline 950 & 25 & 0.08 & 3.5 & 3.15 & 0.18 & $1.32 \times 10^{-12}$ \\
& 60 & 0.35 & 4.6 & 2.24 & 0.22 & $1.67 \times 10^{-12}$ \\
900 & 120 & 0.6 & 10.4 & 0.55 & 0.28 & $2.17 \times 10^{-12}$ \\
& 120 & 0.2 & 5.9 & 1.05 & 0.17 & $4.87 \times 10^{-13}$ \\
850 & 450 & 0.8 & 8.5 & 0.8 & 0.27 & $7.36 \times 10^{-13}$ \\
& 120 & 0.08 & 4.4 & 1.34 & 0.12 & $1.13 \times 10^{-13}$ \\
& 600 & 0.42 & 4.1 & 2.28 & 0.18 & $1.16 \times 10^{-13}$ \\
& 1200 & 0.7 & 4.8 & 3.63 & 0.49 & $1.61 \times 10^{-13}$ \\
\hline
\end{tabular}

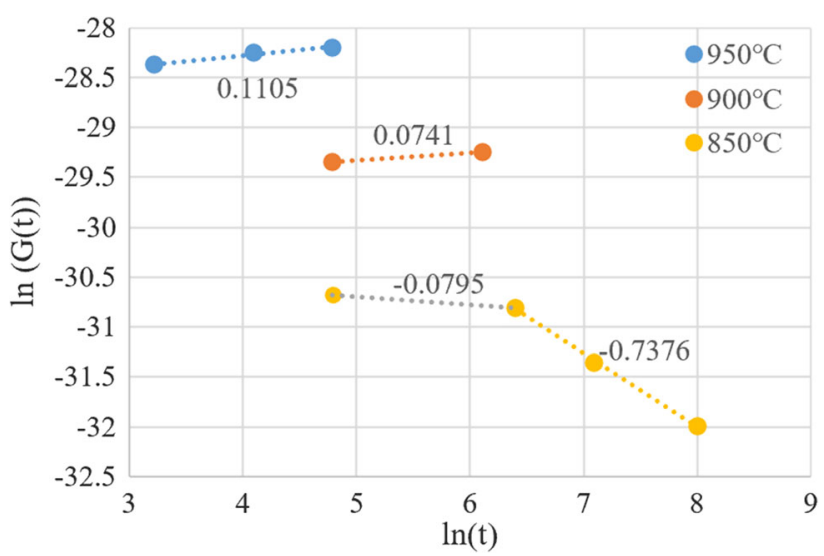

Fig. 11 - Changing growth rate versus time at $950{ }^{\circ} \mathrm{C}$ to $850{ }^{\circ} \mathrm{C}$ (slopes as labeled).

processed in a similar manner and have a recrystallized austenitic grain structure so that texture differences are minimal. In terms of stored energy differences due to grain size, this has been extensively studied for fcc materials. ${ }^{[34-37]}$ These studies indicate that the change in stored energy with increasing grain size for grain sizes of $>80 \mu \mathrm{m}$ is small $(\sim 10 \mathrm{pct})$. Thus, it is reasonable to assume that the average stored energy applies across the grain size distribution in these samples after 0.3 cold strain without barreling. This is the situation for the $\mathrm{Nb}$-free steel (as in Reference [19]) but to account for the effects of $\mathrm{Nb}$ solute drag and SIPs on recrystallization kinetics, a modified JMAK model has been proposed as follows.

The addition of $\mathrm{Nb}$ has been shown above to retard the onset of recrystallization, which is accompanied by the formation of strain-induced precipitates. Table VII also shows that the change in Avrami exponent (at 0.5 recrystallization fraction at $850{ }^{\circ} \mathrm{C}$ ) correlates with a large increase in the pinning force exerted by these SIPs.

The growth rate is given by Zurob et al., ${ }^{[38]}$

$$
G(t)=M\left(F_{\text {rex }}-P(t)\right),
$$

where $M$ is boundary mobility, $F_{\text {rex }}$ is the macroscopic recrystallization driving force, and $P$ is the estimated pinning force at time "t"; $F_{\text {rex }}$ is assumed constant (as discussed above), while $M$ and $P$ for the various conditions come from Table VII. Assuming site-saturated nucleation and $\mathrm{Nb}$ have negligible effect on the number of recrystallization nucleation site, a proposed estimation of the effect of precipitation and solute drag on the overall recrystallization Avrami exponent is given as

$$
n=n_{0}-\frac{\ln (G(t))}{\ln (t)} .
$$

The overall recrystallization Avrami exponent, $n_{0}$, for Fe-30Ni Nb-free steel, has been measured to be 1.3, which can also be predicted by the individual grain size 
Table VIII. Summary of Measured and Predicted Recrystallization Avrami Exponent for the Fe-30Ni Nb-Free and Nb-Containing

Steels

\begin{tabular}{lcccc}
\hline & \multicolumn{2}{c}{ Nb-Free $n$ Values } & \multicolumn{2}{c}{ Nb-Containing $n$ Values } \\
\cline { 2 - 3 } Temperature $\left({ }^{\circ} \mathrm{C}\right)$ & Measured & Predicted & Measured & 1.4 \\
\hline 950 & 1.2 & 1.3 & 1.3 & 1.4 \\
900 & 1.3 & 1.3 & $1.3(<720 \mathrm{~s})$ & 1.4 \\
850 & 1.4 & 1.3 & $0.6(>720 \mathrm{~s})$ & $1.2(<600 \mathrm{~s})$ \\
& & & $0.6(>600 \mathrm{~s})$ \\
\hline
\end{tabular}

class approach. ${ }^{[19]}$ The effect of changing growth rate on Avrami exponent at $950{ }^{\circ} \mathrm{C}$ to $850{ }^{\circ} \mathrm{C}$ is shown in Figure 11. It can be seen in Table VIII that the predicted recrystallization Avrami exponents agree well with the measured data. The combined effect of solute drag and precipitation pinning caused a decrease in recrystallization Avrami exponent at $850{ }^{\circ} \mathrm{C}$ due to the slow coarsening rate, i.e., high pinning force. This approach thus could link quantitatively the precipitation kinetics and recrystallization behavior for large enough starting grain size distributions where stored energy variation are secondary.

\section{CONCLUSION}

Fe-30Ni Nb-free and Nb-containing steel recrystallization kinetics after 0.3 cold strain within the annealing temperature range of $950{ }^{\circ} \mathrm{C}$ to $850{ }^{\circ} \mathrm{C}$ have been measured. The NbC precipitation size evolution and number density have also been examined. The results indicate that strain-induced precipitation nucleation occurs before the onset of recrystallization at 0.3 strain, $950{ }^{\circ} \mathrm{C}$ to $850{ }^{\circ} \mathrm{C}$ with growth and coarsening occurring during recrystallization; the rates of those are influenced by the temperature. With decreasing temperature, the growth and coarsening rates decrease. The presence of SIPs delayed the onset of recrystallization in the $\mathrm{Fe}-30 \mathrm{Ni} \mathrm{Nb}$-containing steel compared to the Fe-30Ni $\mathrm{Nb}$-free steel, i.e., the recrystallization process has been slowed. In contrast, the recrystallized grain size distribution was comparable between the $\mathrm{Nb}$-free and Nb-containing samples after the same strain and annealing temperature, which indicates that the number density of recrystallized nuclei was unaffected. The results suggest that the presence of $\mathrm{Nb}$ retards the onset of recrystallization, but has little effect on the number of nuclei or the recrystallized grain size at a very early stage of recrystallization and hence the final recrystallized grain size.

The effect of $\mathrm{Nb}$ on the recrystallization Avrami exponent is dependent on the growth and coarsening rate of precipitates and the amount of solute left in solution. At a lower temperature, i.e., $850{ }^{\circ} \mathrm{C}, 0.3$ strain, the slower precipitate formation and coarsening rate leads to a prolonged pinning effect on recrystallization, which, combined with reduced boundary mobility, leads to a lower Avrami exponent, i.e., a single Avrami exponent does not cover the entire recrystallization fraction. When full precipitation and coarsening occurs during recrystallization, the pinning forces (Zener and solute drag) decrease as does the recrystallization rate, but the Avrami exponent is not affected.

\section{ACKNOWLEDGMENTS}

The authors would like to thank EPSRC for funding the project and also WMG for their support and facilities.

\section{OPEN ACCESS}

This article is licensed under a Creative Commons Attribution 4.0 International License, which permits use, sharing, adaptation, distribution and reproduction in any medium or format, as long as you give appropriate credit to the original author(s) and the source, provide a link to the Creative Commons licence, and indicate if changes were made. The images or other third party material in this article are included in the article's Creative Commons licence, unless indicated otherwise in a credit line to the material. If material is not included in the article's Creative Commons licence and your intended use is not permitted by statutory regulation or exceeds the permitted use, you will need to obtain permission directly from the copyright holder. To view a copy of this licence, visit http://creat ivecommons.org/licenses/by/4.0/.

\section{REFERENCES}

1. J.J. Jonas and I. Weiss: J. Mater. Sci., 1979, vol. 13, pp. 238-45.

2. S.F. Medina, A. Quispe, and M. Gomez: Metall. Trans. A, 2014, vol. $45 \mathrm{~A}$, pp. $1524-39$.

3. H. Zurob, C. Hutchinson, Y. Brechet, and G. Purdy: Mater. Sci. Eng. A, 2004, vol. 382, pp. 64-81.

4. Y.J. Wang and H.S. Zurob: Appl. Phys. A, 2002, vol. 74, pp. $1213-15$

5. M.J. Jones and F.J. Humphreys: Acta Mater., 2003, vol. 51, pp. 2149-59.

6. W. Yang, D. Yan, and L. Rong: Scripta Mater., 2013, vol. 68, pp. $587-90$.

7. B. Dutta and E.J. Palmiere: Metall. Trans. A, 2003, vol. 34, p. 1237.

8. B. Dutta, E.J. Palmiere, and C.M. Sellars: Acta Mater., 2001, vol. 49, pp. 785-94.

9. P. Cizek, F. Bai, E.J. Palmiere, and W.M. Rainforth: J. Microsc., 2005, vol. 217, pp. 138-51. 
10. P. Cizek, J.A. Whiteman, W.M. Rainforth, and J.H. Beynon: J. Microsc., 2004, vol. 213, pp. 285-95.

11. W. Rainforth, M.P. Black, R.L. Higginson, E.J. Palmiere, C.M. Sellars, I. Papst, P. Warbichler, and F. Hofer: Acta Mater., 2002, vol. 50, pp. 735-47.

12. V. Nagarajan, E.J. Palmiere, and C.M. Sellars: Mater. Sci. Technol., 2013, vol. 25, pp. 1168-74.

13. E.J. Palmiere, P. Cizek, F. Bai, R.M. Poths, J. Turner, B.P. Wynne, and W.M. Rainforth: Mater. Manuf. Process., 2011, vol. 26, pp. 127-31.

14. M.P. Black: Microstructural Evolution of Austenite in a Microalloyed $\mathrm{Fe}-30 \mathrm{Ni}$ Alloy, University of Sheffield, Sheffield, 2002, pp. 118-21.

15. A. Abdollah-Zadeh: The Investigation of Deformation, Recovery, Recrystallization and Precipitation in Austenitic HSLA Steel Analogue Alloys, University of Wollongong, Wollongong, 1996, pp. 254-58.

16. D. Poddar, P. Cizek, H. Beladi, and P.D. Hodgson: Acta Mater., 2015, vol. 99, pp. 347-62.

17. D. Poddar, P. Cizek, H. Beladi, and P.D. Hodgson: Acta Mater., 2014, vol. 80, pp. 1-15.

18. S. Zaefferer, T. Baudin, and R. Penelle: Acta Mater., 2001, vol. 49, pp. 1105-22.

19. M. Ji, C. Davis, and M. Strangwood: Metals, 2019, vol. 9, pp. $1-12$.

20. S. Vervynckt, K. Verbeken, P. Thibaux, and Y. Houbaert: Mater. Sci. Eng. A, 2011, vol. 528, pp. 5519-28.

21. K.B. Kang, O. Kwon, W.B. Lee, and C.G. Park: Scripta Mater., 1997, vol. 36, pp. 1303-08.

22. S.S. Hansen, G.B.V. Sande, and M. Cohen: Metall. Trans. A, 1980, vol. 11A, pp. 387-402.

23. M.J. Luton, R. Dorvel, and R.A. Petkovic: Metall. Trans. A, 1980, vol. 11A, pp. 411-20.
24. K. Mukunthan and E.B. Hawbolt: Metall. Trans. A, 1996, vol. 27, pp. 3410-23.

25. P.O. Malta, D.S. Alves, A.O.V. Ferreira, I.D. Moutinho, C.A.P. Dias, and D.B. Santos: Metall. Trans. A, 2017, vol. 48, pp. 1288-1309.

26. M.K. Rehman and H.S. Zurob: Metall. Trans. A, 2013, vol. 44A, pp. $1862-71$

27. R.P. Reed and R.E. Schramm: J. Appl. Phys., 1969, vol. 40, pp. 3453-58.

28. H.M. Ledbetter and R.P. Reed: J. Phys. Chem. Ref. Data, 1973, vol. 2, pp. 531-617.

29. M.F. Ashby and D.R.H. Jones: Engineering Materials, Pergamon Press, Oxford, 1980.

30. H. Zurob and C.R. Hutchinson: Acta Mater., 2002, vol. 50, pp. 3075-92.

31. B. Dutta and C.M. Sellars: Mater. Sci. Technol., 1987, vol. 3, pp. 197-206.

32. F. Humphreys and M. Hatherly: Recrystallization and Related Annealing Phenomena, 2nd ed., Elsevier, Oxford, 2004, pp. $173-220$.

33. H. Luo, J. Sietsma, and S. van der Zwaag: ISIJ Int., 2004, vol. 44, pp. 1931-36.

34. O. Kwon and A.J. DeArdo: Acta Metall. Mater., 1991, vol. 39, pp. 529-38.

35. R.O. Williams: Acta Metall., 1961, vol. 9, pp. 949-57.

36. I. Baker, L. Liu, and D. Mandel: Scripta Mater. Met., 1995, vol. 32, pp. 167-71.

37. M. Kazeminezhad: Mater. Sci. Eng. A, 2008, vol. 486, pp. $202-07$.

38. H. Zurob, Y. Brechet, and G. Purdy: Acta Mater., 2001, vol. 49, pp. 4183-90.

Publisher's Note Springer Nature remains neutral with regard to jurisdictional claims in published maps and institutional affiliations. 